\title{
Új mütéti képalkotó lehetőség a belsőfül-implantátum elektródasorának dinamikus helyzetmeghatározására
}

\author{
Perényi Ádám dr.* - Nagy Roland dr.* - Horváth Bence - Posta Bálint dr. \\ Dimák Balázs - Csanády Miklós dr. - Kiss József Géza dr. - Rovó László dr. \\ Szegedi Tudományegyetem, Általános Orvostudományi Kar, \\ Fül-Orr-Gégészeti és Fej-Nyaksebészeti Klinika, Szeged
}

\begin{abstract}
Bevezetés: A cochlearis implantátum egy mútétileg behelyezett elektromos eszköz, amely az akusztikus hanghullámokat elektromos jelekké alakítja, közvetlenül a hallóideget stimulálja, így segíti a súlyos fokú hallássérüléssel vagy teljes hallásvesztéssel élők életét. Cochlearis implantációt követően a legjobb rehabilitációs eredmény elérésének technikai feltétele többek között az esetre szabott elektródaválasztás és az elektródasor teljes, kontrollált, szövődménymentes bejuttatása a scala tympaniba, miközben a cochlea belső struktúrája a lehető legkisebb mértékben sérül. A rutin intraoperatív elektrofiziológiai tesztek fontos információt adnak a készülék múködóképességéról és a hallóideg stimulációjáról, azonban nem hagyatkozhatunk rájuk az elektródasor cochleán belüli helyzetének igazolásában. Mivel előfordulhat, hogy a rendelkezésre álló elektrofiziológiai vizsgálatok eredménye megfelelő, és mégis rendellenes helyzetbe kerül az elektróda, az arany standardot a képalkotó vizsgálatok jelentik.

Módszer: Közleményünkben egy modern, hibrid mútő által nyújtott technológiai háttér új alkalmazási területét mutatjuk be. Szimultán kétoldali cochlearis implantációt végeztünk Cochlear Nucleus Slim Modiolar típusú perimodiolaris elektródasorral, a belső fül fejlődési rendellenességével rendelkező betegen. Az intraoperatív képalkotást Siemens Artis pheno C-karos robot digitális szubtrakciós angiográfiás rendszer biztosította valós idejú átvilágító és volumentomográfiás funkcióval.

Eredmények: Az intraoperatív képalkotás által dinamikusan követhető az elektródasor bevezetésének folyamata, ellenőrizhető az elektródasor statikus helyzete, így kiváltható a rutinnak számító posztoperatív képalkotó vizsgálat. A rendellenes helyzetbe kerülő elektródasor pozíciója egy ülésben korrigálható, az újból bevezethető, így elkerülhető az újabb altatással járó, bizonytalan kimenetelú revíziós mútét.

Következtetés: A hibrid mútő jól kontrollált, minimálisan invazív eljárások elvégzését biztosítja. Különösen a hallószerv fejlődési rendellenessége vagy egyéb, az elektródának a cochleába vezetését nehezítő rendellenesség esetén javasolt a mútői képalkotó diagnosztika.

Orv Hetil. 2021; 162(22): 878-883.
\end{abstract}

Kulcsszavak: cochlearis implantátum, Slim Modiolar elektródasor, cochlearis malformatio, hibrid mútő, intraoperatív képalkotás

\section{A novel intraoperative imaging tool to follow the cochlear implant electrode array insertion dynamics}

Introduction: The cochlear implant is a surgically inserted electrical device that converts acoustic sound waves into electrical signals to stimulate the cochlear nerve, thus helps the rehabilitation of people with severe to total hearing loss. One of the most important technical conditions for achieving the best rehabilitation result after cochlear implantation is the personalized choice of electrodes. Additionally, it is vital that there is a complete, controlled, uncomplicated delivery of the electrode array to the scala tympani while minimizing damage to the inner structures of the cochlea. Routine electrophysiological tests provide important information about device functionality and auditory nerve stimulation. However, they probably do not show an abnormal position of the electrode array within the cochlea. Thus, imaging studies remain the gold standard. 
Method: In our paper, we present a novel application field of the modern technological background provided by a hybrid operating room. Simultaneous bilateral cochlear implantation was performed with cochlear implants with perimodiolar electrode array (Nucleus Slim Modiolar) in a patient with cochlear malformation. Intraoperative imaging was provided by a Siemens Artis pheno C-arm robot digital subtraction angiography system with real-time fluoroscopy and volume tomography function.

Results: Intraoperative imaging ensures dynamic follow-up of the introduction and static determination of the position of the electrode array and replaces routine postoperative imaging. If the electrode array was inserted in an abnormal position, the revision can be performed in the same sitting. Also, the revision surgery with a potential risk of uncertain outcome, alongside additional anaesthesia, can be prevented.

Conclusion: The hybrid operating room ensures that well-controlled, minimally invasive procedures are performed. Intraoperative imaging can be imperative in malformed cochleae and conditions that may complicate electrode insertion.

Keywords: cochlear implant, Slim Modiolar electrode array, cochlear malformation, hybrid operating room, intraoperative imaging

Perényi Á, Nagy R, Horváth B, Posta B, Dimák B, Csanády M, Kiss JG, Rovó L. [A novel intraoperative imaging tool to follow the cochlear implant electrode array insertion dynamics]. Orv Hetil. 2021; 162(22): 878-883

(Beérkezett: 2020. október 16.; elfogadva: 2020. november 27.)

\section{Rövidítések}

$\mathrm{CT}=($ computed tomography) komputertomográfia; DSA $=$ (digital subtraction angiography) digitális szubtrakciós angiográfia; ESRT = (electrical evoked stapedius reflex threshold $)$ az elektromosan kiváltott stapedius reflex küszöbe; $\mathrm{MR}=$ (magnetic resonance) mágneses rezonancia; NRT $=$ (neural response telemetry) idegiválasz-telemetria

Cochlearis implantáció során a megfelelő elektródasor pozicionálása kihívást jelenthet olyan esetekben, mint a belső fül fejlődési rendellenessége vagy a hallószerv részleges hiánya, kötőszövetes átalakulása vagy elcsontosodása. Az esetek nagy többségében az ilyen rendellenességek mûtétet megelőzően azonosíthatók szeletelő képalkotó eljárásokkal (CT- és/vagy MR-vizsgálattal).

Az ezen esetek adta behelyezési nehézségek felismerése befolyásolhatja a sebészt a beültetett eszköz (elektródasor) kiválasztásában, vagy módosítást igényelhet a mútéti megközelítés.

Szövődmények még kellő elővigyázatosság és gondosság mellett is kialakulhatnak. Az elektródasornak a cochleába történő bevezetését követően szembesülhetünk azzal, hogy rendellenes helyzetbe került. Ilyen rendellenes pozíció lehet a részleges bevezetés, a megtöretés, a felgyưrődés vagy akár visszatekeredés ( 1 .ábra) és az egyensúlyszervbe kerülés [1-3]. Számos publikáció szerzői beszámoltak már az elektródasor behelyezése során az ún. interscalaris diszlokációról, ami azt jelenti, hogy az elektródasor átszakítja az alapi hártyát, és így a scala tympaniból részben a scala vestibuliba kerül át [ 1 , $4,5]$. Ismerünk olyan eseteket is, amelyeknél évekkel a mútét után az elektródasor migrált a cochleán kívülre $[1,5,6]$.

Klinikai protokollunkban a cochlearis implantáció során alkalmazott általános vizsgálati módszereink az im- pedanciavizsgálat, az elektromosan kiváltott stapediusreflex küszöbének (electrical evoked stapedius reflex threshold, ESRT) mérése és az idegiválasz-telemetria (neural response telemetry, NRT). Ezek a mérési módszerek nem jelzik egyértelmúen az elektródasor rendellenes bevezetését, hanem az elektródasor állapotáról (szakadás, sérülés), környezetének elektromos vezetóképességéről és a közölt elektromos jel által stimulált idegelemekben kiváltható akciós potenciál jelenlétéról adnak információt. A legtöbb, cochlearis implantációt végző központ számára mútéti képalkotó vizsgálat nem áll rendelkezésre, ezért általában a mútét másnapján végeznek képalkotó vizsgálatot, ami lehet röntgenfelvétel, 'conebeam' (kúpsugaras) CT- vagy hagyományos (multi slide) CT-vizsgálat [7].

Amennyiben az elektróda bevezetését követően azonnal felismerjük az elektródasor rendellenes helyzetét, még ugyanabban az ülésben megtörténhet a repozicionálás. Intraoperatív képalkotásra alkalmas készülékek a mobil röntgen, az átvilágító, a fekvő 'cone-beam' CT- és a DSA-készülék. Ha azonban intraoperatív képalkotásra - mint a világ legtöbb, implantációt végző fülészeti mütőjében - egyelőre nincs mód, akkor a korrekció újabb mútétet jelent. Ezért az intraoperatív képalkotás lehetősége és szerepe felértékelődik, és így egy ülésben elvégezhető az elektróda reimplantációja [3, 8-11]. Különösen fontos az elektródasor típusának helyes megválasztása és pozíciójának ellenőrzése a cochlea fejlődési rendellenességei [12] esetében.

A kontrollált, szövődménymentes implantációt nagymértékben elősegíti a modern technológiai háttér. Ezen technológiák készségszintú használata, a pontosan öszszehangolt csapatmunka hatékonysága biztosítja a gyors és eredményes beavatkozások számát. Erre alkalmas, igen effektív közeg lehet a hibrid mútő, mely a hallásja- 


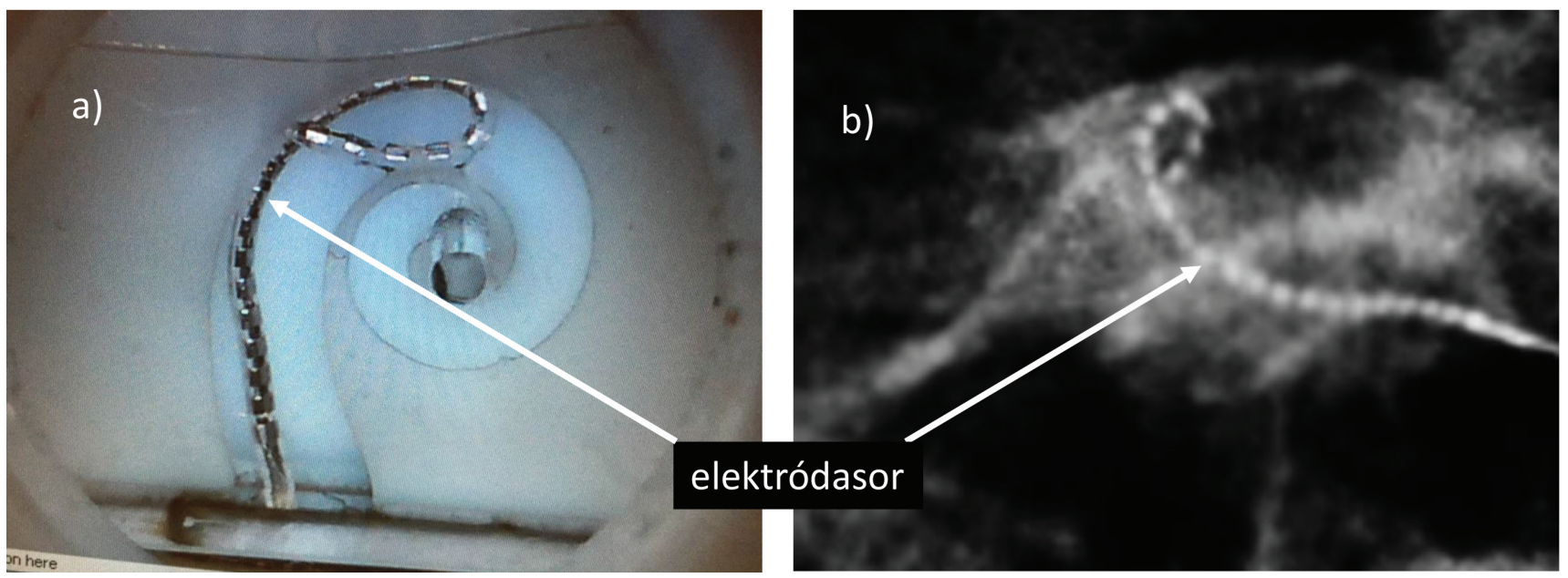

1. ábra $\quad$ A Slim Modiolar elektródasor cochleán belüli visszatekeredése gyakorló modellen (1/a) és posztoperatívan készített röntgenfelvételen (1/b). A modellen az 5. elektródánál, a röntgenfelvételen a 4. elektródánál látható az elektródasor csúcsi szakaszának cochleán belüli visszatekeredése
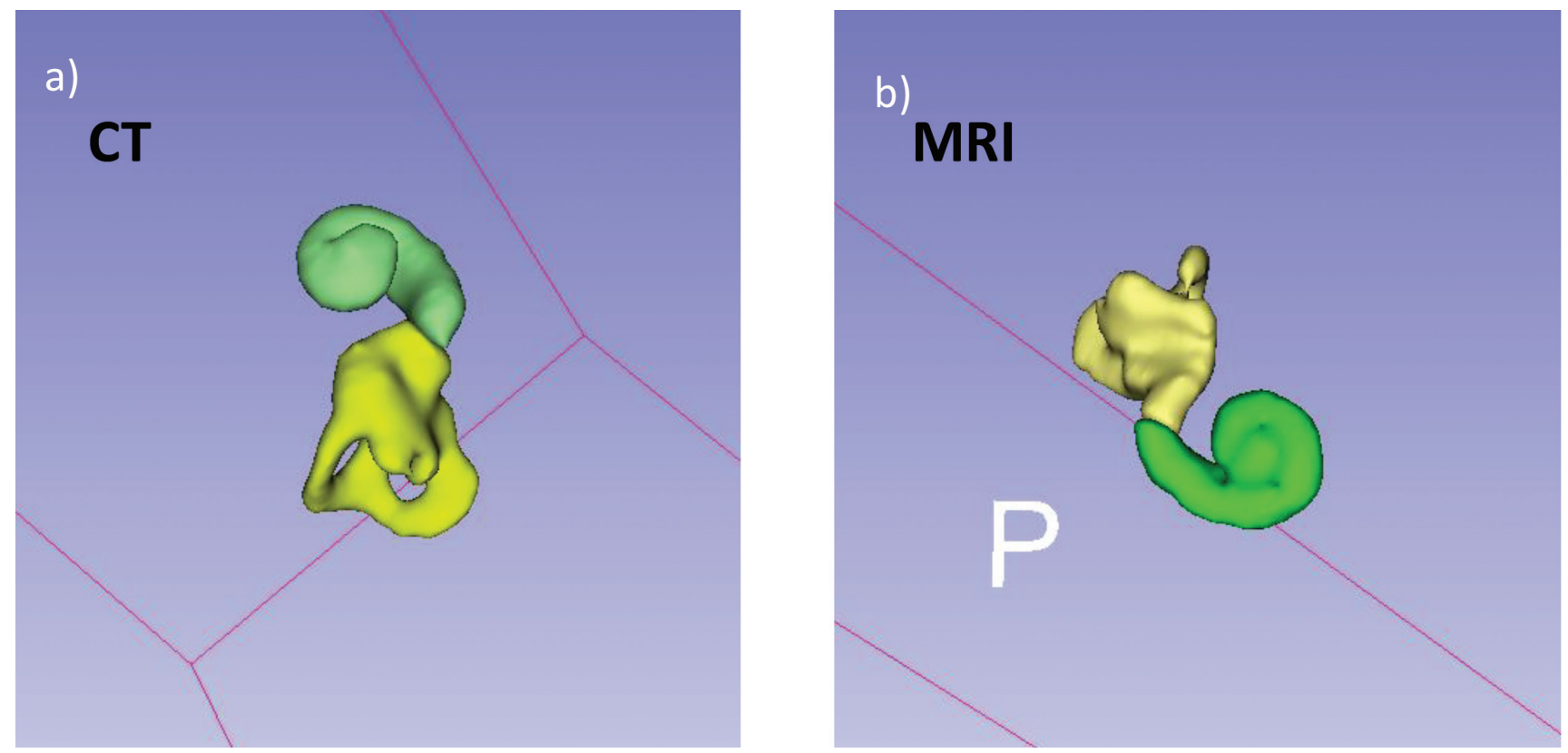

2. ábra

\begin{abstract}
Az 1 éves páciensünk jobb oldali labyrinthusának belső, folyadéktartalmú részéról készített háromdimenziós rekonstrukciós képek, a körülötte lévő csontállomány ábrázolása nélkül; CT alapján $(2 / a)$ és MRI alapján $(2 / b)$. A cochlea átlagos méretű alapi kanyarulatát követően a második kanyarulat csökevényes, mindössze fél fordulatot tesz, és hiányzik a harmadik kanyarulat

$\mathrm{CT}$ = komputertomográfia; MRI = mágnesesrezonancia-képalkotás
\end{abstract}

vító implantáció esetében nemzetközi viszonylatban nem elterjedt módszer. A hibrid mútő egy fejlett operációs tér, amely ötvözi a hagyományos mútőt egy képalkotók által vezérelt intervenciós csomaggal. Ez a kombináció rendkívül összetett, fejlett mútéti eljárásokat tesz lehetővé. Nemcsak a mütőtípusokat kombinálja, hanem csapatok is egyesülnek, és multidiszciplináris klinikusi csoportot alkotnak, felkészülve a betegek összetett igényeinek kielégítésére. Bár a képalkotás hosszú ideje a standard mütők része lehet, a mobil C-karos átvilágító készülék, ultrahang vagy endoszkóp jelenlétével, ezek együttes használata és megfelelő technikai háttere a hibrid mütők jellegzetessége.

\section{Anyag és módszer}

Páciensünk 1 éves, kétoldali teljes hallásvesztéssel élő fiúgyermek, akinek a kivizsgálás részeként elvégzett CT- és MR-vizsgálataival mindkét belső fül malformatiója volt kimutatható. A gyermek mindkét cochleájának ún. III. típusú cochlearis hypoplasiáját azonosítottuk a Sennaroğlu-féle besorolás [12] szerint. Ez az elváltozás azt jelenti, hogy a cochlea átlagos méretû alapi kanyarulatát követően a második kanyarulat csökevényes, mindössze fél fordulatot tesz, és hiányzik a harmadik kanyarulat. A cochlea belső szerkezete (scala tympani, media és vestibuli) megtartott. Ez a cochleamalformatio társul- 
hat az egyensúlyszerv fejlődési rendellenességével, így esetünkben a lateralis ívjáratok részleges hiányával (2. ábra).

A két fül cochlearis implantációját egy ülésben, 2020ban, a Szegedi Tudományegyetem Szent-Györgyi Albert Klinikai Központjának hibrid mútőjében végeztük el, Cochlear Nucleus CI632 típusú, perimodiolaris tulajdonságú elektródasorral rendelkező implantátummal (Cochlear Ltd., Sydney, Ausztrália). Az intraoperatív képalkotást Siemens Artis pheno (Siemens Healthcare GmbH, Erlangen, Németország) robot DSA-rendszer biztosította.

A cochlearis implantációhoz a legelterjedtebb mútéti módszert alkalmaztuk: retroauricularis feltárást követően részleges mastoidectomiát végeztünk, majd vigyázva az arcidegre, posterior tympanotomiás nyílást készítettünk. Az elektródasort ezen keresztül bejuttatva a dobüregbe, a cochlea kerek ablakán keresztül teljesen bevezettük a cochlea scala tympani járatába. A rutin elektrofiziológiai mérési protokollt (impedancia, ESRT, NRT) követtük.

\section{Eredmények}

Az elektródasor cochleába történő bevezetésének folyamatát a C-karos DSA-készülék segítségével, az átvilágító funkcióval követtük külön-külön a két oldalon (3. és 4. ábra).

Az elektródasor bevezetésekor az operáló fülsebész nem érzékelt akadályozó tényezőt, és az intraoperatíven elvégzett rutin elektrofiziológiai mérések az implantátumok múködőképességét igazolták. A második implantátum beültetését követően ugyanazzal a C-karos DSAkészülékkel rétegfelvételeket készítettünk a koponyáról (5. ábra).

Az implantátumhoz tartozó külső beszédprocesszorok első programozásakor - amelyet a mưtétet követő negyedik héten végeztünk - a gyermeknél egyértelmú hallásélményt tapasztaltunk. Az implantátum 22 stimu-

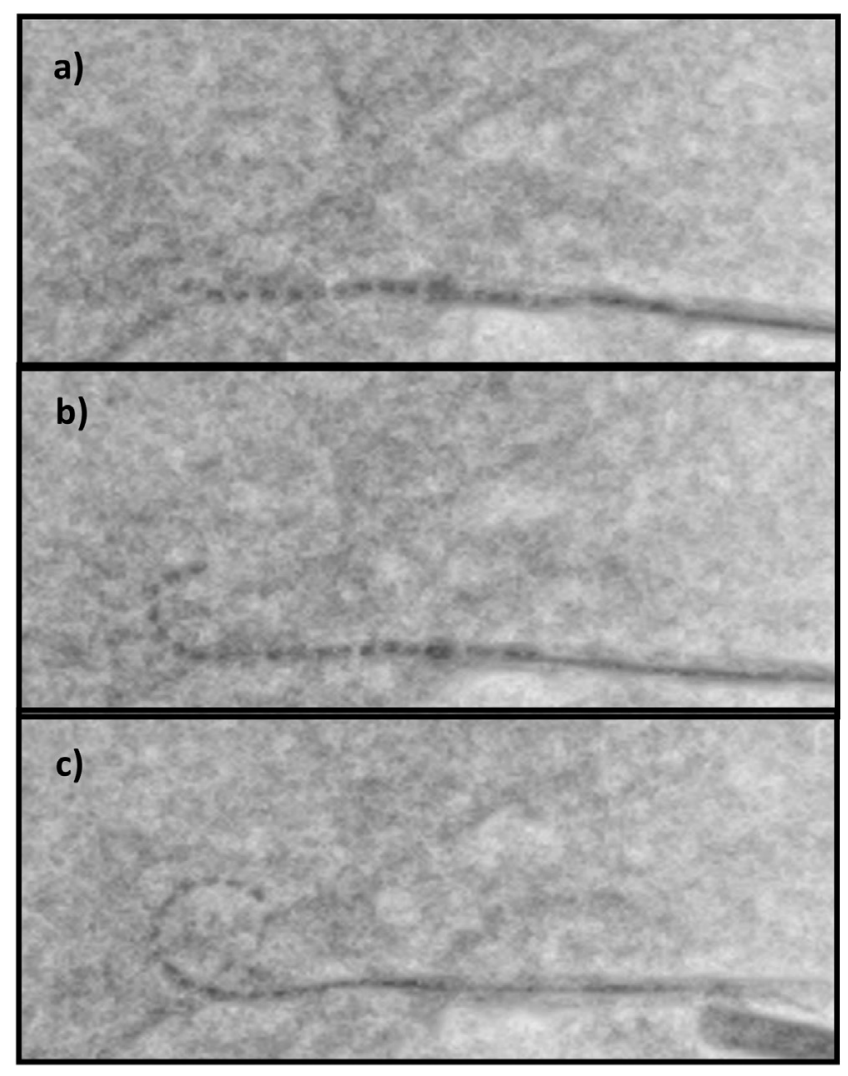

4. ábra C-karos DSA-készülék segítségével valós idejű átvilágító képsor készíthető az elektródasor bevezetéséról. Az elektródasor vége a cochlea basalis kanyarulatának medialis caudalis részében (4/a), cranialis részében $(4 / \mathrm{b})$ és a teljes bevezetés állapotában $(4 / \mathrm{c})$

lálóponttal rendelkezik, melyek segítségével meghatároztuk a gyermek elektromos komfortküszöbét. Az elektromos komfortküszöb az a legmagasabb áramintenzitás-érték, amely a hallópálya intenzív stimulálását jelenti, de még nem kelt kellemetlen, túl hangos érzést. A gyermek mindkét oldalon, minden elektróda esetében érdeklődéssel figyelt a hangként érzékelt elektromos jelekre.
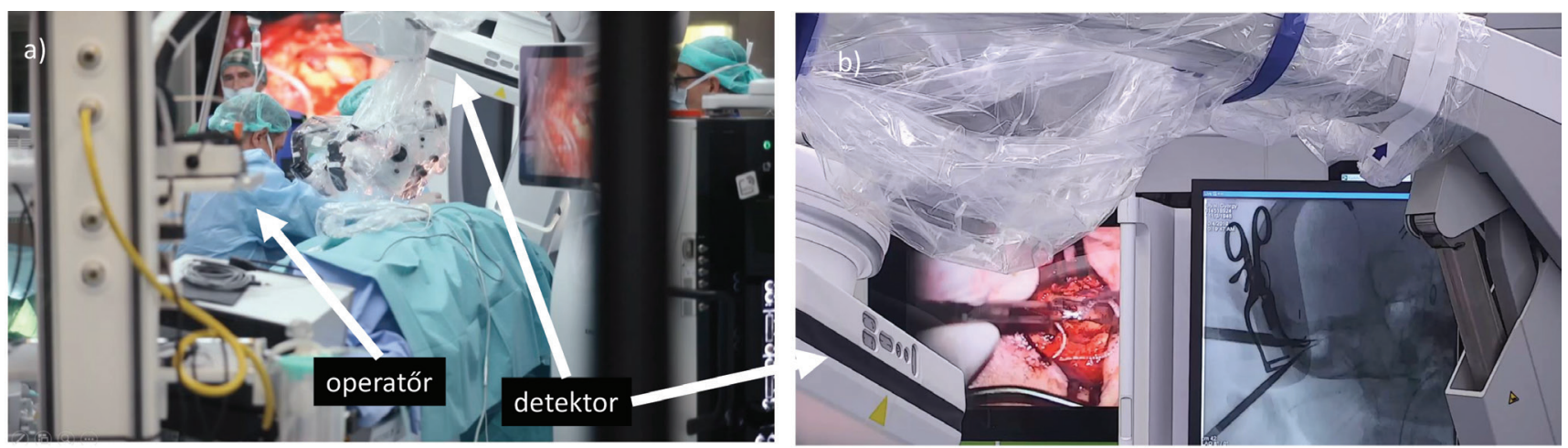

3. ábra

Mútői helyzetkép. A C-karos DSA-készülék helyzete a mútőasztalhoz és az operatőrhöz képest (3/a ábra). A 3/b ábra bal oldalán, a C-karos DSA készülék 'flat panel' detektorának takarásában lévő monitoron a mikroszkópról kivezetett mútéti kép, a jobb oldalán lévő monitoron a valós idejű átvilágító kép látható, az elektróda bevezetésekor

DSA = digitális szubtrakciós angiográfia 


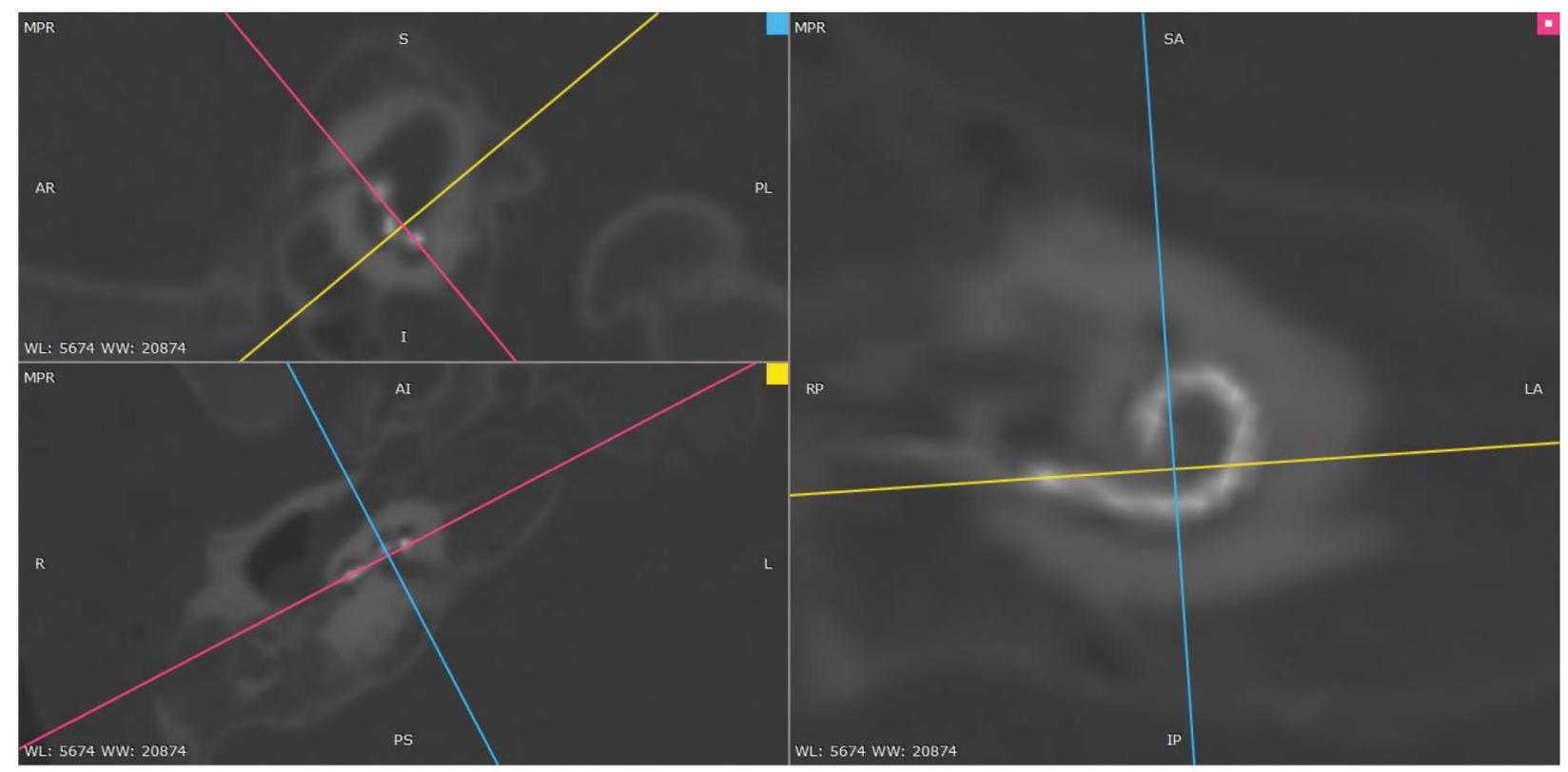

5. ábra

A Siemens Artis pheno készülékkel készített, több síkban rekonstruált volumentomográfiás felvétel. A jobb oldali képen az ún. cochlearis nézetet mutatjuk be a cochlea alapi kanyarulatáról, benne a teljesen bevezetett és perimodiolaris helyzetű elektródasorral

A későbbiekben havi rendszerességgel jelent meg hozzátartozóival állapotellenőrzésre, melyeken újabb beszédprocesszor-programozás történt az elektromos komfortküszöb változásának követésére. Édesanyja hónapról hónapra újabb eredményeket osztott meg: kezdetben a gyermek felfigyelt a külső zajokra, a beszédhangokra, majd az egyszerű utasításokra. A mútétet követő kilencedik hónapra a ritmika nélküli gügyögést tudatos, egyszerű hangformálás váltotta fel. A gyermek környezetében jelen lévő hangok, a szülők és a fejlesztőpedagógus által tanított hangok utánzását meghatározó eredményként könyvelhetjük el a beszédfejlődésének útján. A hallás mellett a gyermek mozgáskoordinációja is jelentősen fejlődött.

\section{Megbeszélés}

A cochlearis implantáció követelménye az inszerciós trauma minimalizálása mellett a minél jobb beszédértés lehetőségének biztosítását lehetővé tevő, elektródasorral felszerelt implantátum beültetése [13, 14]. A vékony perimodiolaris elektróda ötvözi ezen előnyöket, ugyanakkor bevezetésekor más elektródatípusokhoz képest gyakoribb jelenség az elektródasor csúcsi részének cochleán belüli visszacsavarodása $[1,3,9-11,13]$. Amennyiben ez a szövődmény még sebzárás előtt észlelésre kerül, jó eséllyel korrigálható ugyanabban az ülésben. A közleményünkben bemutatott módszer - az elektródasor bevezetésekor végzett átvilágítás - valós időben képes követni az elektródasor útját és helyzetét a cochleán belül. A cochlea funkcionális rendszerét tartalmazó hártyás labyrinthust kompakt csontállomány veszi körül, ezért vizuálisan nem tudjuk követni az operációs mikroszkóppal az elektróda útját. A rendelkezésre álló rutin elektrofiziológiai vizsgá- latokkal nem ismerhető fel biztonsággal az elektródasor rendellenes helyzete, és az operáló sebész sem érzékeli azt. A valós idejű képalkotó vizsgálattal azonnal felismerhető, ha az elektródasor a modiolustól eltávolodik, viszszacsavarodik, megtörik vagy az egyensúlyszervbe kerül. Az elektródasort kissé visszahúzva vagy teljesen eltávolítva - az elektródasor típusától függően - az jó eséllyel korrigálható és jó pozícióba helyezhető vissza. A III. típusú cochleahypoplasiás esetünkben a basalis kanyarulat átlagos nagyságú, megtartott volt. Cochlearis hypoplasia malformatióban a rövid egyenes elektródasor beültetését ajánlják [12]. Esetünkben azért választottuk a vékony, előgörbített elektródát, mert 1 éves páciensünknél fontosnak tartottuk a beszédfejlődés szempontjából az elektródasor modiolushoz közeli helyzetét és a cochlea szerkezetében okozott trauma minimalizálását.

A Szegedi Tudományegyetem Szent-Györgyi Albert Klinikai Központjában múködő hibrid műtő a legmodernebb képalkotó készülékkel felszerelt egység. A Siemens Artis pheno C-karos robot DSA-készülék egyesíti a mobil röntgen, az átvilágító és a 'cone-beam' CT-készülékek előnyeit: nagy teljesítményű, gyors, minden irányba jól pozicionálható sugárforrással és 'flat panel' detektorral rendelkezik, ami lehetóvé teszi, hogy az elektróda bevezetését a cochleába valós időben követhessük átvilágítással, nagy felbontású monitoron. Emellett volumentomográfia is készíthető vele, amely a 'cone-beam' CTnek megfelelő, nagy felbontású képeket biztosít alacsony sugárdózissal és kevés fém mútermékkel [15]. Esetünkben az átvilágítás módszerével rendellenességet nem tapasztaltunk. Az elektróda bevezetését követően elvégzett, alacsony sugárdózisú volumentomográfia alapján igazoltuk, hogy az elektródasor teljesen bevezethető volt, és a modiolushoz közel került. 


\section{Következtetés}

A hibrid mútő aszeptikus környezete egyesíti a sebészeti berendezéseket, műszereket, mütéti asztalokat, operációs lámpákat, berendezést kezelő rendszereket a karokra rögzített fejlett képalkotó rendszerekkel együtt, és lehetőséget kínál kombinált képalkotással vezérelt eljárások végrehajtására, minimálisan invazív módszerekkel. Ezek a korszerű mütőszobák lehetővé teszik a képalkotás-vezérelt mütét és a nyitott feltárások kombinációját is. Ez a technológia új eljárások kifejlesztéséhez vezetett, amelyek elönyös lehetőségeket kínálnak a komplex betegségben szenvedő páciensek számára [16-18].

A cochlearis implantációs centrumok számára ajánljuk az intraoperatív képalkotás bevezetését jól kontrollált, minimálisan invazív eljárások biztosítására. A C-karos röntgenátvilágító berendezések fejlesztőitől új innovációs eredményekre számítunk a készülékek rutinszerü, könnyű használatában, akár külön a fej-nyak sebészet igényeinek megfelelően. Az intraoperatív képalkotás kiváltja a rutinszerúen az első posztoperatív napon több nézetben végzett röntgenvizsgálatot, mely az életkorból adódóan nem együttmúködő gyermekek esetében a mozgási mútermékek miatt korlátozottan értékelhető lehet, és a vizsgálat megismétlését teheti szükségessé.

Ezen korszerû módszerek protokollszerü alkalmazásával a rendellenes helyzetbe kerülő elektródasor korrekciója egy ülésben elvégezhető, így kiváltható a mútétet követő röntgenvizsgálat, elkerülhető az újabb altatással és mútéti megterheléssel járó revízió.

Anyagi támogatás: A közlemény megírása, illetve a kapcsolódó kutatómunka anyagi támogatásban nem részesült.

Szerzői munkamegosztás: P. Á. és N. R. megosztott első szerzőként jegyzik a kéziratot. P. Á.: Az ábrák megszerkesztése, az intraoperatív képalkotás kivitelezése, a kézirat szövegezése. N. R.: Az ábrák megszerkesztése, az elektrofiziológiai vizsgálatok elvégzése, a kézirat szövegezése. H. B.: A képalkotó vizsgálatok rekonstrukciójának elkészítése és az intraoperatív képalkotás kivitelezése. P. B.: A szakirodalom áttekintése, a kézirat véglegesítése. D. B.: A szakirodalom áttekintése, elektrofiziológiai mérések elvégzése. Cs. M.: A kézirat szakmai véleményezése és a publikációra való felkészítése. K. J. G.: Az elektrofiziológiai mérések ellenőrzése, az eredmények értékelése; tudományos tanácsadás. R. L.: Az implantációs team vezetője; a cochlearis implantáció elvégzése, a végleges kézirat véleményezése, a publikáció folyamatának nyomon követése, irányítása. A cikk végleges változatát valamennyi szerző elolvasta és jóváhagyta.

Érdekeltségek: A szerzőknek nincsenek érdekeltségeik.

\section{Irodalom}

[1] Ishiyama A, Risi F, Boyd P. Potential insertion complications with cochlear implant electrodes. Cochlear Implants Int. 2020; 21: 206-219.

[2] Adunka O, Kiefer J. Impact of electrode insertion depth on intracochlear trauma. Otolaryngol Head Neck Surg. 2006; 135: 374-382.

[3] Zuniga MG, Rivas A, Hedley-Williams A, et al. Tip fold-over in cochlear implantation: case series. Otol Neurotol. 2017; 38: 199-206.

[4] Saeed SR, Selvadurai D, Beale T, et al. The use of cone-beam computed tomography to determine cochlear implant electrode position in human temporal bones. Otol Neurotol. 2014; 35: 1338-1344.

[5] Dietz A, Wennström M, Lehtimäki A, et al. Electrode migration after cochlear implant surgery: more common than expected? Eur Arch Otorhinolaryngol. 2016; 273: 1411-1418.

[6] Rader T, Baumann U, Stöver T, et al. Management of cochlear implant electrode migration. Otol Neurotol. 2016; 37: e341e348.

[7] Ramos de Miguel Á, Argudo AA, Borkoski Barreiro SA, et al. Imaging evaluation of electrode placement and effect on electrode discrimination on different cochlear implant electrode arrays. Eur Arch Otorhinolaryngol. 2018; 275: 1385-1394.

[8] Ramos-Macias A, De Miguel AR, Falcon-González JC. Mechanisms of electrode fold-over in cochlear implant surgery when using a flexible and slim perimodiolar electrode array. Acta Otolaryngol. 2017; 137: 1129-1135.

[9] Aschendorff A, Briggs R, Brademann G, et al. Clinical investigation of the nucleus slim modiolar electrode. Audiol Neurootol. 2017; 22: 169-179.

[10] Sabban D, Parodi M, Blanchard M, et al. Intra-cochlear electrode tip fold-over. Cochlear Implants Int. 2018; 19: 225-229.

[11] McJunkin JL, Durakovic N, Herzog J, et al. Early outcomes with a slim, modiolar cochlear implant electrode array. Otol Neurotol. 2018; 39: e28-e33.

[12] Sennaroğlu L, Bajin MD. Classification and current management of inner ear malformations. Balkan Med J. 2017; 34: 397-411.

[13] Schieferbein V, Bredemann J, Schmitt R, et al. Influence of patient-specific anatomy on medical computed tomography and risk evaluation of minimally invasive surgery at the otobasis. Eur Arch Otorhinolaryngol. 2019; 276: 375-382.

[14] Nagy R, Jarabin JA, Dimák B, et al. Possibilities for residual hearing preservation with Nucleu CI532 Slim Modiolar electrode array. [A maradványhallás megőrzésének lehetőségei cochlearis implantáció során Nucleus CI532 Slim Modiolar elektródasorral.] Orv Hetil. 2018; 159: 1680-1688. [Hungarian]

[15] Perényi Á, Bella Z, Baráth Z, et al. Role of cone-beam computed tomography in diagnostic otorhinolaryngological imaging. [A cone-beam komputertomográfia alkalmazása a fül-orr-gégészeti képalkotásban.] Orv Hetil. 2016; 157: 52-58. [Hungarian]

[16] Nollert G, Wich S. Planning a cardiovascular hybrid operating room: the technical point of view. Heart Surg Forum 2009; 12: E125-E130.

[17] Schaadt J, Landau B. Hybrid OR 101: A primer for the OR nurse. AORN J. 2013; 97: 81-100.

[18] Fuchs-Buder T, Settembre N, Schmartz D. Hybrid operating theater. [Hybridoperationssaal.] Anaesthesist 2018; 67: 480487. [German]

(Perényi Ádám dr.,

Szeged, Tisza Lajos krt. 111., 6725 e-mail: perenyi.adam@med.u-szeged.hu) 